\title{
Disposal practices of unused and expired pharmaceuticals among general public in Kabul
}

\author{
Mohammad Bashaar $^{1 *}$, Vijay Thawani ${ }^{2}$, Mohamed Azmi Hassali $^{3}$ and Fahad Saleem ${ }^{4}$
}

\begin{abstract}
Background: Most of the medicine users remain unaware about the disposal of unused or expired medicines. The aim of this study was to know the disposal practices of unused and expired medicines among the general public in Kabul.

Methods: This was a descriptive, cross-sectional survey, conducted through face-to-face interviews using prevalidated structured questionnaire. Returned questionnaires were double-checked for accuracy. Statistical Package for Social Science (SPSS) version 23 was used for statistical analysis.

Results: Total of 301 valid questionnaires were returned with a response rate of 100\% in which $73.4 \%$ men and $26.6 \%$ women participated. More than half of the respondents were university graduates. Interestingly, $83.4 \%$ of the interviewees purchased medicines on the prescription of which $47.2 \%$ were university graduates, while $14.6 \%$ purchased medicine over the counter. Among the respondents, 46.5/100 purchased antibiotics and the remaining purchased NSAIDs, anti-hypertensive and anti-diabetic medicines. Significantly, 97/100 checked the expiry date of medicine before buying. Majority (95.3\%) of the respondents' stored medicines at home. $77.7 \%$ of the respondents discarded the expired medicines in household trash. Majority of respondents held government responsible for creation of awareness for proper medicine disposal. Almost entire sample (98\%) felt that improper disposal of unused and expired medicines can affect the environment and health.

Conclusion: Gaps exist in practices, therefore robust, safe and cost-effective pharmaceutical waste management program supported with media campaign is needed. Healthcare practitioners and community pharmacists should offer training to educate customers on standard medicine disposal practices.
\end{abstract}

Keywords: Pharmaceutical, Disposal, Unused, Medicine, Expired, Afghanistan, Practices

\section{Highlights}

- Disposal practices of unused and expired pharmaceuticals among general public in Kabul, Afghanistan

- We examine the knowledge and practices towards unused and expired pharmaceutical among general public

- Improving the understanding of future medication waste disposal among families

\footnotetext{
* Correspondence: mbashaar@gmail.com

'Health Policy Analyst, SMART Afghan International Trainings \& Consultancy, Kabul, Afghanistan

Full list of author information is available at the end of the article
}

- Increasing information on safe and standard pharmaceutical waste

- Help the policymakers to take firm steps to encourage standard pharmaceutical waste management

\section{Background}

Increasing disease incidence and prevalence necessitate healthcare practitioners to prescribe and dispense different medications. The consumer (patients) are not able to use all the dispensed medications because of adverse effects, alteration of dosage, feeling healthy, medications reaching the expiration date, promotional practices by manufacturers', physicians' prescribing practices, or dispensers' practices $[1,2]$. According to World Health Organization 
(WHO), more than half of all medication is inappropriately prescribed, prescribed and sold, which causes unnecessary storage and creates environmental threat [3]. Non-adherence to medication can also cause storage of left over medicines at home. According to WHO 50\% of patients fail to take medicine correctly [4]. Therefore, it is usual that, families and patients are in possession of unused or expired medications and its risks have gained attention across the world [5].

When there is a concern of unused and expired medication storage, patients and family members require clear guidance about its disposal [1]. The presence of unused and expired medications in cabinets and cupboards is a potential threat and can be harmful to humans, environment and wildlife [6-8]. Specifically, the presence of discarded medicines in waterways and drinking water is a serious and multifaceted issue that has gained national and international attention with the public, lawmakers, and regulators [9]. For instance, non-steroidal antiinflammatory drug (NSAID) diclofenac has been shown to induce renal failure in vultures following the ingestion of carrion from cattle treated with this drug [10]. The improper disposal of unused and expired medication challenges the environment for example in the USA many drugs such as acetaminophen, verapamil, and estradiol are found in waterways. [11]. The trace levels of ethinyl estradiol, the active component of a common oral contraceptive, impairs sexual development and the feminization of fish [12]. Evidence shows that the presence of antibiotics in water may lead to antibiotic resistance [13] and in long term may cause genetic effects in humans and marine life [9]. In Kabul, Afghanistan, the byproducts of a mass vaccination campaign of 1.6 million against polio in October 2008 were discarded in the local municipal waste, causing infectious injury to individuals searching waste dump sites for reusable items. Other medical wastes including pharmaceuticals have been found lying in the open land-fills near hospitals in urban areas [14]. Similarly, it has been found that more than 60 hospitals in Kabul do not have incineration facility or access to other essential Health Care Waste Management (HCWM) equipments $[15,16]$.

The HCW includes all the waste generated by healthcare establishments, research facilities, and laboratories [17]. Pharmaceutical waste is one constituent of the HCW, which contains expired pharmaceuticals or no longer needed, contaminated items, or pharmaceuticals, which need clear and systematic disposal approach to get rid of its hazardous effects.

Therefore, WHO's European Centre for Environment and Health in France, set up an international working group to produce a practical guide, addressing particularly the problems of HCWM in developing economies [18]. In addition, some programs such as Disposal of Unwanted Medication Properly (DUMP) campaign was launched in
New Zealand [19] and in Canada ENVIRx disposal program was initiated [20]. Yet some countries do not have official state guidelines or protocols for the disposal of unwanted and unused medications [21-23]. In Afghanistan, the National Medicine Policy (NMP) emphasizes the disposal of expired medicines by allocating one percent of the cost of all medicines to be provided in Afghanistan, for pharmaceutical product waste management activities. The General Directorate of Pharmaceutical Affairs (GDPA) was held responsible for the systematic monitoring and evaluation of drugs and medical supplies waste management plan implementation throughout the country [24] Despite these policy recommendations the pharmaceutical waste disposal is facing many shortfalls, and the current system of waste disposal is substantially dysfunctional. To tackle these concerns the Ministry of Public Health $(\mathrm{MoPH})$ formulated Comprehensive Healthcare Waste Management Plan (HCWMP) for the System Enhancement for Health Action in Transition (SEHAT) Project [25] for the handling of pharmaceutical items requiring destruction [26]. These are general policy statements on waste and disposal of pharmaceutical products and lack clear, detailed and transparent procedures [26]. In developing countries like Afghanistan, the inappropriate management of $\mathrm{HCW}$ is due to lack of resources, implementation of legislative policies and control [27]. Thus strengthening of policies dealing with $\mathrm{HCW}$ disposal, especially in developing economies is needed [5]. In addition, public awareness and different practical approaches are required to dispose unused medications.

No study has so far been conducted regarding disposal practices of unused and expired pharmaceuticals among the general public in Kabul. In Afghanistan, no data is available about the disposal knowledge and practices towards expired medication. This study was therefore planned with the aim to report the current practices and attitudes of general public towards disposal of unused and expired pharmaceuticals.

\section{Methods \\ Study design}

This was a descriptive, cross-sectional survey, conducted through face-to-face interviews using pre-validated structured questionnaire. The study was conducted in Kabul between January to March 2016.

\section{Study population}

The study population was of either gender, which included students, public and private sector employees, storekeepers and population from other walks of life, above the age of 18 years, who were local residents of Kabul, regardless of ethnicity or employment status. 


\section{Sampling/sample size}

A non-probability sampling technique (convenience method) was employed to reach to the representative population easily in districts four and 10 of Kabul.

\section{Study instrument}

Literature was reviewed to develop the questionnaire $[8,19,23,28-32]$. The questionnaire consisted of two sections. Section one was about respondent's personal information including gender, age, marital status, the level of education, ways of procuring medicines, classes of medicine used and checking the expiry date of medicine before procuring. Section two of the questionnaire included respondents' practices and attitudes concerning unused and expired medication disposal. This included five questions related to the existing unused medicines at their home, what they did with expired and unused medicines, who according to them was responsible to create awareness for proper disposal, and whether improper disposal affected environment and health. The respondents were required to choose from the given descriptions in the questionnaire that best illustrated their usual practices.

The questionnaire was adapted to the local context and translated into the local language and back translated into English to avoid any misinterpretation. For face and content validity, the questionnaire was reviewed by experts and pretested on 15 respondents. Following the pilot testing, minor changes were made based on respondents' recommendations. For the internal consistency (reliability) assessment, Cronbach's alpha test was performed.

\section{Data collection method}

The data collectors were trained and prevailed upon to explain the purpose of the study to their potential respondents prior to administering the survey questionnaire. Participation in survey was voluntary. The questionnaire was provided in two languages (Dari and English) to make it more comprehensible. Face-to-face interview method was used by filling up questionnaires.

\section{Data analysis}

All returned questionnaires were double-checked for accuracy and then the collected data were feed into an Excel spreadsheet Dataset. Then the cleaned data was transferred to Statistical Package for Social Science (SPSS) version 23 for analysis. Descriptive statistics (descriptive, crosstab and chi-square) were used.

\section{Ethical considerations}

Written informed consent was obtained from all the respondents before the start of the survey. Participation in this research was voluntary. Participant identity was kept confidential. The Ethical Approval was received from
Institutional Review Board of Institute of Public Health under reference number 98092 .

\section{Results \\ Demographic data}

All the approached 301 individuals agreed to participate in the study and none declined. Thus participant response rate was $100 \%$. Of the 301 respondents, 221 (73.4\%) were men and 80 (26.6\%) were women. Maximum (104; 34.6\%) respondents were aged 32 years and above. One hundred and sixteen (38.6\%) respondents had up to secondary education, $163(54.2 \%)$ were university graduates and 22 (7.3\%) were illiterate [Table 1]. The Cronbach's alpha for all items was 0.70 .

Table 1 Demographics and knowledge about procuring medicines

\begin{tabular}{|c|c|c|}
\hline \multirow{2}{*}{$\begin{array}{l}\text { Variables and categories } \\
\text { Gender }\end{array}$} & \multicolumn{2}{|c|}{$\begin{array}{l}\text { Number of } \\
\text { responses (\%) }\end{array}$} \\
\hline & & \\
\hline Men & 221 & $73.4 \%$ \\
\hline Women & 80 & $26.6 \%$ \\
\hline \multicolumn{3}{|l|}{ Age } \\
\hline $18-24$ & 103 & $34.2 \%$ \\
\hline $25-31$ & 94 & $31.2 \%$ \\
\hline 32 - above & 104 & $34.6 \%$ \\
\hline \multicolumn{3}{|l|}{ Marital Status } \\
\hline Single & 160 & $53.2 \%$ \\
\hline Married & 141 & $46.8 \%$ \\
\hline \multicolumn{3}{|l|}{ Level of Education } \\
\hline Illiterate & 22 & $7.3 \%$ \\
\hline Primary & 45 & $15 \%$ \\
\hline Secondary & 71 & $23.6 \%$ \\
\hline University & 163 & $54.2 \%$ \\
\hline \multicolumn{3}{|l|}{ Ways of Procuring Medicines } \\
\hline Purchased on prescription & 251 & $83.4 \%$ \\
\hline Purchased over the counter & 44 & $14.6 \%$ \\
\hline Received from friend/ colleague & 3 & $1 \%$ \\
\hline Purchase based upon the advice of a relative or friend & 3 & $1 \%$ \\
\hline \multicolumn{3}{|l|}{ Classes of medicine used } \\
\hline NSAIDs & 61 & $20.3 \%$ \\
\hline Antibiotic & 140 & $46.5 \%$ \\
\hline Anti-hypertensive & 42 & $14 \%$ \\
\hline Anti-diabetic & 23 & $7.6 \%$ \\
\hline Other & 35 & $11.6 \%$ \\
\hline \multicolumn{3}{|l|}{ Do you check expiry date of the medicines before procuring } \\
\hline Yes & 292 & $97 \%$ \\
\hline No & 5 & $1.7 \%$ \\
\hline Don't know & 4 & $1.3 \%$ \\
\hline
\end{tabular}




\section{Knowledge about procuring medicines}

Regarding knowledge about "ways of procuring medicines", 251 (83.4\%) respondents purchased medicines on prescription and 44 (14.6\%) purchased medicine over the counter. Commonly purchased medicines were antibiotics $(n=140$; $46.5 \%)$, NSAIDs $(n=61,20.3 \%)$, anti-hypertensive $(n=42$; $14 \%)$, and anti-diabetic $(n=23,7.6 \%)$. The majority of respondents $(n=292 ; 97 \%)$ checked the expiry date of medicines, prior to purchase [Table 1]. In addition, it was observed that 142 university graduates procured medicines on prescription. Similarly, 159 university graduates checked medicine expiry date prior to purchase [Fig. 1].

Table 2 shows that among all respondent the majority $(159 / 301)$ of university graduates checked the expiry date of any medicine prior to its procurement.

In addition, most of the university graduates $(n=159)$ said that improper disposal of unused and expired medicines can affect both the environment and health (Table 3).

\section{Practices and attitudes towards unused and expired medication disposal}

Table 4 shows responses to the items intended to measure public practices and attitudes towards unused and expired medication disposal and its environmental impact. When asked, did any quantity of purchase medicine remain unused at their home, majority of the respondents $(n=287$; 95.3\%) replied positively. A slim majority (52.2\%) of the interviewed respondents kept the unused medicines at home until expired. Most of the respondents $(n=234$; $77.7 \%$ ) were throwing the expired medicine in household trash. Six out of $10(60.8 \%)$ of the respondents said that government was responsible to create awareness for proper disposal of unused and expired medicines. A large majority of the sample $(n=295 ; 98 \%)$ reported that improper disposal of unused and expired medicines can affect the environment and health. More than $95 \%$ of the respondents had unused medicine stored at home, and most of these were antibiotics.

\section{Discussion}

Currently medicine waste management and disposal is a hot topic grabbing attention because it has been realized that improper disposal can contaminate the environment and pose the risk to water, air, agricultural products, and food chain and even harm animals/ livestock. Therefore, studies have been conducted throughout the world about this issue to find the policy solutions. However this is the first study from Kabul, Afghanistan.

The Table 1 shows that majority of the respondents purchased medicines on prescription, which shows rational medicine purchase practices. Results from unused medication collection program in California showed that more than $50 \%$ of OTC medicines were discarded unused, compared to $45 \%$ of prescription medicines [9]. Of total sample, nearly $50 \%$ procured antibiotics and the rest procured other classes of medicines such as NSAIDs, anti-hypertensive and anti-diabetic. In procuring medicines the educational level of the respondents played the crucial role, where 142 university graduates purchased medicines on prescription and in contrast only 19 purchased them OTC for selfmedication. This indicates that respondent education status correlated with level of awareness of the potential health risks associated with OTC purchase of medicines which has been shown to be taking of excessive drug dosage, continuous medicine use, polypharmacy and drug interactions [33].

Interestingly, in this study nearly all respondents checked the expiry date of medicine, prior to its purchase, while in contrast in the Indian state of Gujarat many were not aware of the expiry date of medicines [34]. It is of paramount significance that prior to purchase or use of any medicine, the expiry date must be checked, otherwise it may lead to serious harmful effects [34].

The current study shows that practices towards disposal of unused and expired pharmaceutical were optimal but more than $95 \%$ of the respondents surveyed had left-over medications at home and half of the interviewed population kept the unused medicines at home until expired, which is a source of potential health threat [35]. Borrowing and

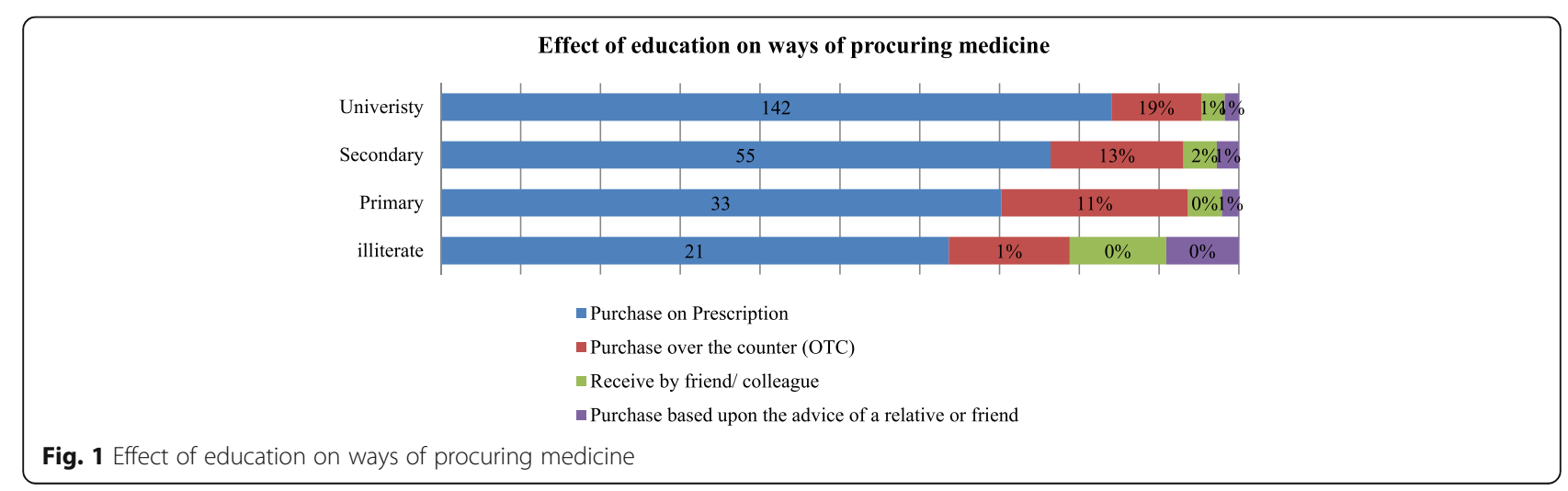


Table 2 Respondents views about checking expiry date of the medicines before procuring

\begin{tabular}{llll}
\hline & \multicolumn{2}{l}{$\begin{array}{l}\text { Do you check expiry date of the medicines before } \\
\text { procuring }\end{array}$} \\
\cline { 2 - 4 } & Yes & No & Don't know \\
\hline Illiterate & 19 & 1 & 2 \\
Primary & 43 & 2 & 0 \\
Secondary & 71 & 0 & 0 \\
University & 159 & 2 & 2 \\
Total & 292 & 5 & 4 \\
\hline
\end{tabular}

sharing of medications is known to be associated with several risk factors such as polypharmacy and multiple, chronic comorbidity [36], however, this attitude was rarely observed among the respondents of this study.

The majority of survey respondents asserted, that they throw away the expired medicines in the household trash which is similar to findings of others [23]. Housewives in Busan city of Korea disposed unused medications using the standard garbage bag [37]. Previously it was believed that proper method of unused or expired medications disposal was to flush down the toilet / drain, as opposed to discarding them in the trash, where animals or humans would be more likely to encounter them [38]. More than $10 \%$ of the respondents flushed the expired medications down the toilet or sink, which are similar to the practices followed by the people in Kuwait, UK and USA [22, 39], where it is the best practice for liquid medications [23]. Some of the respondents returned unused and expired pharmaceuticals to medical stores, which is similar to community practice in the USA and Malaysia [32, 39]. All these approaches towards safe disposal of leftover pharmaceuticals play significant role in reducing the introduction of pharmaceuticals to the environment since it can cause environmental, human health, and safety hazards $[28,40]$.

Clear guidance about disposal of unused and expired medicines is lacking and there is a knowledge and practice deficit in appropriate methods for medicines disposal. The Nebraska Medication Education for Disposal Strategies (MEDS) has suggested the "golden standard" for safe, legal, environmentally sound disposal, to put tamperresistant boxes in pharmacies that will allow consumers to

Table 3 Effect of Education on attitudes towards the effects of improper disposal of unused and expired medicines on environment and health

\begin{tabular}{llll}
\hline Level of Education & Yes & Don't Know & Total \\
\hline Illiterate & 22 & 0 & 22 \\
Primary & 44 & 1 & 45 \\
Secondary & 70 & 1 & 71 \\
University & 159 & 4 & 163 \\
Total & 295 & 6 & 301 \\
\hline
\end{tabular}

Table 4 Respondents' practices and attitudes concerning unused and expired medication disposal

\begin{tabular}{|c|c|c|c|}
\hline Questions & & $\mathrm{N}$ & $\%$ \\
\hline \multirow{2}{*}{$\begin{array}{l}\text { Did any quantity of purchase } \\
\text { medicine remain unused at } \\
\text { your home? }\end{array}$} & Yes & 287 & 95.3 \\
\hline & No & 14 & 4.7 \\
\hline \multirow[t]{6}{*}{$\begin{array}{l}\text { What do you do with the } \\
\text { unused medicines? }\end{array}$} & $\begin{array}{l}\text { Throw away in } \\
\text { household garbage }\end{array}$ & 43 & 14.3 \\
\hline & Donate to hospital & 29 & 9.6 \\
\hline & $\begin{array}{l}\text { Give to friends } \\
\text { or relatives }\end{array}$ & 4 & 1.3 \\
\hline & $\begin{array}{l}\text { Return to medical } \\
\text { stores }\end{array}$ & 64 & 21.3 \\
\hline & $\begin{array}{l}\text { Keep at home } \\
\text { until expired }\end{array}$ & 157 & 52.2 \\
\hline & $\begin{array}{l}\text { Flush unused } \\
\text { medications } \\
\text { in toilet or sink }\end{array}$ & 4 & 1.3 \\
\hline \multirow[t]{5}{*}{$\begin{array}{l}\text { What do you do with the } \\
\text { expired medicines? }\end{array}$} & $\begin{array}{l}\text { Throw away in } \\
\text { household garbage }\end{array}$ & 234 & 77.7 \\
\hline & $\begin{array}{l}\text { Flush expired } \\
\text { medications } \\
\text { in toilet or sink }\end{array}$ & 36 & 12 \\
\hline & $\begin{array}{l}\text { Give to friends } \\
\text { or relatives }\end{array}$ & 4 & 1.3 \\
\hline & $\begin{array}{l}\text { Return to medical } \\
\text { store }\end{array}$ & 22 & 7.3 \\
\hline & Don't know & 5 & 1.7 \\
\hline \multirow{4}{*}{$\begin{array}{l}\text { Who is responsible to create } \\
\text { awareness for proper disposal } \\
\text { of unused and expired medicines? }\end{array}$} & Government & 183 & 60.8 \\
\hline & $\begin{array}{l}\text { Pharmaceutical } \\
\text { Industries }\end{array}$ & 36 & 12 \\
\hline & Public & 17 & 5.6 \\
\hline & Pharmacist & 65 & 21.6 \\
\hline \multirow{2}{*}{$\begin{array}{l}\text { Improper disposal of unused } \\
\text { and expired medicines can } \\
\text { affect the environment and health. }\end{array}$} & Yes & 295 & 98 \\
\hline & Don't Know & 6 & 2 \\
\hline
\end{tabular}

bring medicines back to knowledgeable pharmacists [40]. In Sweden and Korea, more people return unused medicines to a pharmacy for correct disposal, as they have realized the environmental concerns posed by expired medicines [29, 37]. Thus, the Afghan government needs to be proactive to launch feasible expired pharmaceutical collection programs, such as Francisco's Safe Medicine Disposal program, Dispose a Med program, Chemical Control Program, Sharps Waste Disposal Program Expired medications drop-off operation in California USA [28] Medications Return Program or Take-back programs in Canada [41] and Meds Disposal in Europe [42, 43]. However, if a take-back program is unavailable, household trash is possible as recommended by White House Office of National Drug Control Policy (ONDCP). Prescription medicines along with the patient information should be removed from their original containers and mixed with some undesirable substance, such as kitty litter, coffee 
grounds, or sawdust inside a sealable plastic bag container and disposed in the trash [44].

The American Pharmacists Association recommends that unwanted medications be crushed or dissolved in water prior to mixing with the undesirable substance [45]. Health care organizations such as Connecticut Department of Environmental Protection suggest four easy steps for medication disposal: First; keep medication in its original container and cross out patient's name or remove the label. Second; modify the medications to discourage consumption, for example for pills or capsules: add a small amount of water to partially dissolve them; for liquid medications: add salt, flour, charcoal, kitty litter or powdered spice to make a pungent, unsightly mixture that discourages anyone from eating it; for blister packs: wrap pack containing pills in multiple layers of duct tape. Third; seal and conceal and tape medicine container cover closed with packing or plastic tape and then put inside opaque plastic bag or container. Precautionary, the medicines should not be concealed with food items because animals could accidentally eat or drink them. Finally; discard the container in the trash [46].

Despite the suggested alternatives, the proper and best option for the safe disposal of pharmaceutical waste is incineration which requires third party intervention for the collection of unwanted medicines [47]. For example, in Australia, the return of unused medication service runs a medication collection and destruction service through community pharmacies which employ a high-temperature incineration method approved by the US Environmental Protection Agency [23].

Thus, in order to orient the community on proper and standard disposal practices, it is important to increase awareness and undertake training interventions among the public by the government, pharmacists, and pharmaceutical industries. A significant role can be played by community pharmacist being on the forefront in guiding and providing proper education and awareness to the community [34]. Therefore, it is equally essential that their knowledge of proper medication disposal is current, complete, and accurate. Currently, about 20\% of pharmacists report learning about medication disposal during pharmacy school [48]. In Taiwan, an educational pharmacist intervention booklet has been designed to teach their customers in how to use and store the medications properly [49]. It is important for the government to focus on the medicines provided free at public hospitals, since it has been shown that free availability of medicine is associated with higher medication wastage. This result is significant in terms of national policy development around medication supplies, and targeting medication wastage [50].

The study results suggest that government, pharmacist, and pharmaceutical industry are responsible to create awareness, which is consistent with the suggestions made by others [32]. Prior to implementing any drug take-back program, stronger campaign and significant involvement of the patient, healthcare professionals and the government officials is required to avoid any possible barriers such as lack of information and techniques of proper disposal of expired medication [51].

It is found that most of the respondents were aware of the hazardous environmental and health impact of improper disposal of unused and expired medicines, which is similar to the concerns of Serbian people [30]. Since the active pharmaceutical ingredients (API) in medicines could be unsafe to the environment, and incorrect disposal of medicines will contaminate the environment $[52,53]$. The presence of pharmaceuticals even in small quantities potentially harms aquatic life [54]. A survey from Afghanistan has predicted environmental impact of pharmaceutical waste to be "very low" since, usage of antineoplastic/ cytotoxic preparations, poisons, and hormonal contraceptives in Afghanistan remains low. It further states that a high enough volume of pharmaceutical waste is not currently being generated to create a significant environmental or waste management problem [26].

Bias in medicine disposal practices has been observed due to lack of proper awareness, therefore, there is a pressing need for raising public awareness on proper disposal of unused and expired pharmaceuticals at home and hospitals [29]. In addition, the establishment of a national policy and a legal framework, training of personnel, is essential in successful pharmaceutical waste management [18].

\section{Conclusion}

To further strengthen the ongoing debate on safe disposal practices of unused and expired pharmaceuticals among general public, this survey from Kabul in Afghanistan suggests that, the government is responsible to devise a robust safe and cost effective pharmaceutical waste management program and to make the people aware of hazardous effects of expired and unused medications through comprehensive media campaign. Moreover, like other healthcare practitioners, and community pharmacists are in an excellent position to educate patients on medicine disposal, therefore leveraging their knowledge through training programs and continuous education is of importance.

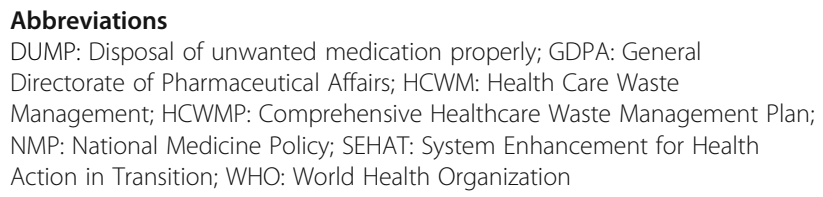

Funding

This research received no specific grant from any funding agency in the public, commercial or not-for-profit sectors. 


\section{Availability of data and materials}

All data generated or analyzed during this study are included in this published article. However, the datasets of the current study available from the corresponding author on reasonable request.

\section{Authors' contributions}

MB Carried out the study design and execution of the research work and writing of the initial draft of the manuscript. VT Writing and expert review of the manuscript. MAH and FS Reviewed the statistical analysis for appropriate writing of the manuscript and expert review of the manuscript. All authors read and approved the final version of the manuscript.

\section{Competing interests}

The authors declare that they have no competing interests.

\section{Consent for publication}

Not applicable

\section{Ethics approval and consent to participate}

Written informed consent was obtained from all the respondents before the start of the survey. The Ethical Approval was received from local IRB of Afghan Institute of Public Health.

\section{Author details}

${ }^{1}$ Health Policy Analyst, SMART Afghan International Trainings \& Consultancy, Kabul, Afghanistan. ${ }^{2}$ Professor of Pharmacology, People's College of Medical Sciences \& Research Centre, Bhanpur, Bhopal 462037, India. ${ }^{3}$ Professor of Social and Administrative Pharmacy, School of Pharmaceutical Sciences, Universiti Sains Malaysia, 11800 Minden, Penang, Malaysia. ${ }^{4}$ Faculty of Pharmacy and Health Sciences, University of Baluchistan, Quetta, Pakistan.

Received: 2 October 2016 Accepted: 20 December 2016 Published online: 07 January 2017

\section{References}

1. Seehusen DA, Edwards J. Patient practices and beliefs concerning disposal of medications. J Am Board Fam Med. 2006;19(6):542-7.

2. Ruhoy IS, Daughton CG. Beyond the medicine cabinet: an analysis of where and why medications accumulate. Environ Int. 2008;34(8):1157-69.

3. WHO. Challenges in expanding access to essential medicines; 2004. 2014. http://apps.who.int/medicinedocs/en/d/Js5571e/2.html. Accessed 30 June 2016.

4. WHO. The world medicines situation. 2004. http://apps.who.int/ medicinedocs/pdf/s6160e/s6160e.pdf Accessed 30 June 2016.

5. Ananth AP, Prashanthini V, Visvanathan C. Healthcare waste management in Asia. Waste Manag. 2010;30(1):154-61

6. Daughton CG, Ternes TA. Pharmaceuticals and personal care products in the environment: agents of subtle change? Environ Health Perspect. 1999; 107 Suppl 6:907.

7. Zuccato E, Castiglioni S, Fanelli R, Bagnati R, Reitano G, Calamari D. Risks related to the discharge of pharmaceuticals in the environment: further research is needed. Pharmaceuticals in the Environment. Springer; 2004. p. 431-37.

8. Vollmer G. Disposal of pharmaceutical waste in households-a European survey. Green and Sustainable pharmacy. Springer; 2010. p. 165-78.

9. Wu M, Atchley D, Greer L, Janssen S, Rosenberg D, Sass J. Dosed without prescription: preventing pharmaceutical contamination of our nation's drinking water. Natural Resources Defense Council White Paper. 2009. p. 1-60.

10. Oaks JL, Gilbert M, Virani MZ, Watson RT, Meteyer CU, Rideout BA, Shivaprasad H, Ahmed S, Chaudhry MJI, Arshad M. Diclofenac residues as the cause of vulture population decline in Pakistan. Nature. 2004:427(6975):630-3.

11. Boehringer S. What's the best way to dispose of medications. Pharm Lett. 2004;20(4).

12. Jobling S, Williams R, Johnson A, Taylor A, Gross-Sorokin M, Nolan M, Tyler $C R$, van Aerle $R$, Santos E, Brighty G. Predicted exposures to steroid estrogens in UK rivers correlate with widespread sexual disruption in wild fish populations. 2005

13. Costanzo SD, Murby J, Bates J. Ecosystem response to antibiotics entering the aquatic environment. Mar Pollut Bull. 2005:51(1):218-23.

14. IRIN. Medical waste poses health risk in urban areas. In: IRIN News. 2008.
15. Harhay MO, Halpern SD, Harhay JS, Olliaro PL. Health care waste management: a neglected and growing public health problem worldwide. Trop Med Int Health. 2009;14(11):1414-7.

16. Solberg KE. Trade in medical waste causes deaths in India. Lancet. 2009; 373(9669):1067

17. Pruss A, Cirouit E, Rushbrook P. Definition and characterization of healthcare waste. Safe Management of Wastes From Health-Care Activities. 1999. p. 2-46.

18. Prüss A, Giroult E, Rushbrook P. Safe management of wastes from healthcare activities: World Health Organization; 1999.

19. Braund R, Peake BM, Shieffelbien L. Disposal practices for unused medications in New Zealand. Environ Int. 2009;35(6):952-5.

20. Gagnon E. Pharmaceutical disposal programs for the public: A Canadian perspective. Ottawa, Ontario: Health Canada, Environmental Impact Initiative; 2009.

21. Götz K, Keil F. Drug disposal in private households: does the disposal of pharmaceuticals via domestic sanitary devices contribute to water contamination. Z Umweltchem Ökotox. 2007:18:180-8.

22. Abahussain EA, Ball DE. Disposal of unwanted medicines from households in Kuwait. Pharm World Sci. 2007;29(4):368-73.

23. Tong AY, Peake BM, Braund R. Disposal practices for unused medications around the world. Environ Int. 2011;37(1):292-8.

24. MOPH. Afghanistan National Medicines Policy. In: Ministry of Public Health IRoA, editor. General Directorate of Pharmaceutical Affairs, Avicenna Pharmaceutical Institute. 2014. p. 49.

25. MOPH. Comprehensive Health Care Waste Management Plan (HCWMP) for the System Enhancement for Health Action in Transition (SEHAT) project. In: Ministry of Public Health, Afghanistan. 2014.

26. GDPA. Technical Report: Waste Management of Pharmaceuticals in Afghanistan. Submitted to the US Agency for International Development by the Strengthening Pharmaceutical Systems (SPS) Program. Arlington, VA: Management Sciences for Health. In: Ministry of Public Health. 2015

27. Fayaz SH, Hiquchi M, Hirosawa T, Sarker MAB, Djabbarova Z, Hamajima N. Knowledge and practice of universal precautions among health care workers in four national hospitals in Kabul, Afghanistan. J Infect Dev Ctries. 2014;8(04):535-42.

28. Glassmeyer ST, Hinchey EK, Boehme SE, Daughton CG, Ruhoy IS, Conerly O, Daniels RL, Lauer L, McCarthy M, Nettesheim TG. Disposal practices for unwanted residential medications in the United States. Environ Int. 2009;35(3):566-72.

29. Persson M, Sabelström E, Gunnarsson B. Handling of unused prescription drugs - knowledge, behaviour and attitude among Swedish people. Environ Int. 2009;35(5):771-4.

30. Kusturica MP, Sabo A, Tomic Z, Horvat O, Šolak Z. Storage and disposal of unused medications: knowledge, behavior, and attitudes among Serbian people. Int J Clin Pharm. 2012;34(4):604-10.

31. Vellinga A, Cormican S, Driscoll J, Furey M, O'Sullivan M, Cormican M. Public practice regarding disposal of unused medicines in Ireland. Sci Total Environ. 2014;478:98-102.

32. Azad MAK, Ansary MRH, Akhter MA, Al-Mamun SM, Uddin M. Disposal practice for unused medications amongthe students of the International Islamic UniversityMalaysia. J Appl Pharm Sci. 2012;2(7):11.

33. Hughes CM, McElnay JC, Fleming GF. Benefits and risks of self medication. Drug Saf. 2001;24(14):1027-37.

34. Shah A, Parmar S, Kumkishan A, Mehta A. Knowledge, Attitude and Practice (KAP) Survey Regarding the safe use of Medicines in rural area of Gujurat. Adv Trop Med Pub Health. 2011;1(2):66-70.

35. De Bolle L, Mehuys E, Adriaens E, Remon J-P, Van Bortel L, Christiaens T. Home medication cabinets and self-medication: a source of potential health threats? Ann Pharmacother. 2008;42(4):572-9.

36. Ellis J, Mullan J. Prescription medication borrowing and sharing: risk factors and management. Aust Fam Physician. 2009;38(10):816.

37. Hwang B-D. Storage and disposal of unused medications for housewives in the Busan Metropolitan City. Korean J Health Serv Manag. 2013;7(2):69-79.

38. Chasler J. Tips for Disposal of Unused and Expired Medications - Pharmacy Practice News - American College of Clinical Pharmacology. 2011. Available at: https://www.accp1.org/documents/

TipsforDisposalofUnusedorExpiredMedications.pdf Accessed 20 Jan 2016.

39. Kuspis D, Krenzelok E. What happens to expired medications? A survey of community medication disposal. Vet Hum Toxicol. 1996;38(1):48-9.

40. Lamb A. Pharmacists' Role in Safe and Legal Medication Disposal. 2012.

41. Returning unused and expired medications in British Columbia. Health Products Stewardship Association. Available at http://www.healthsteward. ca/returns/british-columbia. Accessed 28 Sept 2016. 
42. Macarthur D. Any old drugs? Two schemes for the disposal of unwanted medicines in Europe. Pharm J. 2000;264(7082):223-4.

43. Lubick N. Drugs in the environment: do pharmaceutical take-back programs make a difference? Environ Health Perspect. 2010;118(5):A210.

44. ONDCP. Proper Disposal of Prescription. In. Edited by Office of National Drug Control Policy. United States of America. 2009. https://www.ncjrs.gov/ ondcppubs/publications/pdf/prescrip_disposal.pdf. Accessed 29 Sept 2016.

45. American Pharmacists Association. APhA provides guidance on proper medication disposal: use with respect and discard with care. 2007. 2013.

46. Connecticut Department of Environmental Protection 2015 Htdopmao-tcOp, 2015. http://www.ct.gov/deep/lib/deep/p2/individual/ consumerpharmdisposalfactsheet.pdf. Accessed 16 June 2016.

47. Smith CA. Managing pharmaceutical waste. J Pharm Soc Wis. 2002;5:17-22.

48. Jarvis Cl, Seed SM, Silva M, Sullivan KM. Educational campaign for proper medication disposal. Journal of the American Pharmacists Association: JAPhA. 2009;49(1).

49. Chien H-Y, Ko J-J, Chen Y-C, Weng S-H, Yang W-C, Chang Y-C, Liu H-P. Study of medication waste in Taiwan. J Exp Clin Med. 2013;5(2):69-72.

50. West LM, Diack L, Cordina M, Stewart D. A cross-sectional survey of the Maltese general public on medication wastage. Int J Clin Pharm. 2016;38(2): 261-70.

51. Bond C, Blenkinsopp A, Raynor DK. Prescribing and partnership with patients. Br J Clin Pharmacol. 2012;74(4):581-8

52. Arkaravichien W, Ruchipiyarak T, Thawinwan W, Benjawilaikul S. Genotoxicity Assessment of Mercuric Chloride in the Marine Fish Therapon jaruba: A Threat to the Environment from Practice of Drug Disposal in Thailand. Environment Asia. 2014;7(1):13-8. doi:10.14456/ea.2014.3.

53. Daughton CG. Cradle-to-cradle stewardship of drugs for minimizing their environmental disposition while promoting human health. II. Drug disposal, waste reduction, and future directions. Environ Health Perspect. 2003;111(5):775

54. Bound JP, Kitsou K, Voulvoulis N. Household disposal of pharmaceuticals and perception of risk to the environment. Environ Toxicol Pharmacol. 2006; 21(3):301-7.

\section{Submit your next manuscript to BioMed Central and we will help you at every step:}

- We accept pre-submission inquiries

- Our selector tool helps you to find the most relevant journal

- We provide round the clock customer support

- Convenient online submission

- Thorough peer review

- Inclusion in PubMed and all major indexing services

- Maximum visibility for your research

Submit your manuscript at www.biomedcentral.com/submit 